on February 6, 1834, and died in 1913, was not only one of the pioneers of bacteriology, but also made important contributions to other fields of medicine. In addition to being the first to describe the causal organism of diphtheria in 1875, he described acromegaly in 1884, two years before Pierre Marie ; inoculated primates with syphilis fifteen years before Metchnikoff; isolated colonies of bacteria on solid media in the form of Sturgen's glue nine years before Koch ; was the first to produce tuberculosis experimentally in animals by the injection of milk from infected cows, thereby establishing the bovine origin of the disease; and described the typhoid bacillus before Eberth. Klebs pursued his medical education in his native town of Konigsberg under Rathke, Helmholtz, Burdach and Werther, and later in Würzburg under Virchow, Kölliker, Leydig and Scanzoni. $\mathrm{He}$ led a wandering life, being successively professor at Berne, Würzburg, Prague, Zurich and the Rush Medical College, Chicago. His contributions to pathological anatomy and physiology included the first experimental production of valvular disease of the heart and the recognition of bacterial infection in the production of the subsequent endocarditis, the description of hæmorrhagic pancreatitis as a rapidly fatal disease, the introduction of the paraffin embedding method and his textbooks on pathological anatomy (1869-76) and general pathology (1887-89). Klebs also took an active part in the foundation of three important medical journals, namely, the Correspondenz-Blatt für Schweizer Aerzte (1871), which some years ago was renamed Schweizer medizinische Wochenschrift, the Archiv für experimentelle Pathologie und Pharmakologie (1873) and the Prager Medizinische Wochenschrift (1876).

\section{Work of the Government Chemist}

THE report of the Government Chemist on the work of the Government Laboratory for the year ending March 31, 1935 (London : H.M. Stationery Office, $9 d$. net), outlines the work carried out in the Government Laboratories for the Admiralty, Ministry of Agriculture and Fisheries, the Air Ministry, Crown Agents for the Colonies, Board of Customs and Excise, Ministry of Health, Home Office, Post Office and other Government departments. The total number of samples examined during the year was 522,788 , as compared with 503,592 in the previous year. There was an increase of 26,594 in the number of samples examined in the laboratory at Clement's Inn Passage, and decreases at the Custom House laboratory and at the chemical stations of 232 and 7,166 respectively, the latter being due to the closing of the Manchester chemical station and the transfer of the examination of samples of tea to tea inspectors of Customs and Excise. The principal increases occurred in the number of samples of hydrocarbon oils, beers, wine, spirits, cocoa and chocolate, samples for duty under the Import Duties Act, 1932, Safeguarding of Industries Act, 1921, tobacco and silk exportations, samples of sugar composite goods and British sugar, and in samples taken under the national marking schemes.
The hydrocarbon oils duty has involved the examination of nearly 17,000 samples for assessment of duty on importation or drawback of duty on exportation, the increase being due to the duty of 1d. per gallon charged on oils other than light oils. Many of the samples had to be examined for other dutiable substances, such as alcohols, esters and chemicals listed by the Board of Trade under Part I of the Safeguarding of Industries Act. The growing use of duty-free spirits and industrial methylated spirits in industry involves an increase in the consultative work of the Laboratory, apart from the examination of samples to ascertain whether the conditions of use laid down by the Commissioners of Customs and Excise have been fulfilled. The number of samples of cocoa, chocolate and wine submitted for examination increased by 1,400; samples of beer increased by 1,609, of silk and rayon by 1,866 , while the Laboratory was also called upon to deal with the testing of animal and vegetable fibres and hairs of all kinds under the Import Duties Act. The number of samples of tobacco and snuff examined has also increased, and improved methods for the analysis of tobacco have been studied. Much work has been carried out on the revision of existing methods and the investigation of new methods of detection and determination of substances.

\section{Petroleum and Tar Oils as Insecticides}

AN important paper by Dr. Hubert Martin on the standardisation of petroleum and tar oils and preparations as insecticides appears in the Annals of Applied Biology (22, 334). In recent years, a great deal of attention has been devoted by research workers and by the appropriate Government departments to the standardisation and specification of the sprays and dusts employed for the control of insect pests and diseases infesting agricultural and horticultural crops. An important body of knowledge on the chemical constitution and physical properties of these materials is scattered through the literature of the subject, and is so extensive as to be available only to relatively few. Of the many insecticides now in use, the petroleum and tar distillate oils occupy a very important position, and their use, already widespread, is expanding. Dr. Martin gives an extended and critical review of the published information of the chemical and physical factors defining these products, and in addition incorporates much original work of his own.

Dr. Martin sets out in a concise and ordered way how the chemical and physical criteria can be corre. lated with insecticidal and phytocidal properties, and finally builds up from his own analyses specifications which he considers are available for judging the suitability of these oils, and preparations made from them, for their various uses as insecticides. In addition, the analytical methods available are considered, and the most suitable set out with supporting evidence in considerable detail. This paper is an important step towards the realisation of the hope, that a reasonable standard of efficiency and safety in use 
and of uniformity of quality may be attained for these important products. It is published with the object of ascertaining how the various specifications will work out in practice, and thus it is advisable that interested manufacturers, horticultural advisers, and large users will give it the attention it deserves. The Council of the Association of Applied Biologists has consented to the paper being reprinted for sale, the price being $2 s$. post free; it is obtainable from the author (Research Station, Long Ashton, Bristol).

\section{International Congress of Mining, Metallurgy and Applied Geology}

THE seventh International Congress of Mining, Metallurgy and Applied Geology was opened at the Sorbonne, Paris, on October 20, and will continue until October 26. The President of the Republic, M. Lebrun, was present at the inaugural session. Sir Robert Hadfield, the delegate of the Iron and Steel Institute, presented to M. Lebrun a copy of the picture in the Bodleian Library, Oxford, depicting Roger Bacon presenting a book to the Chancellor of the University of Paris. Sir Robert also presented a miniature knife of steel made by Michael Faraday during the years 1819-24 while he was residing at the Royal Institution. The steel contains 0.74 per cent platinum. The weight of the blade is onehundredth of an ounce, and that of the complete knife, one-twentieth of an ounce. Sir Robert suggested that the knife should be handed either to Dr. Leon Guillet, head of the Ecole Centrale des Arts et Manufactures, or to the Ecole des Mines.

\section{Pasteur Institute of India, Kasauli}

In the thirty-third annual report for 1933 of the Kasauli Pasteur Institute, the Director, Lieut.-Col. Shortt, gives an account of the work of the Institute for 1933. The total number of patients attending the Institute and its various centres was 19,524, an increase of 4,406 as compared with the previous year. Such a large number of patients indicates the widespread threat of rabies in India. The vaccine used was carbolised 5 per cent Paris sheep vaccine, and three out of every four cases with face bites received antirabic serum in addition, as this appears to improve the results obtained. Deducting some 2,000 cases that did not complete the treatment, and 1,446 cases whom it was considered did not require treatment, there were 1,356 Europeans and 14,582 natives treated. There were no deaths among the Europeans, and 83 deaths among the natives, a combined percentage death-rate of only $0 \cdot 52$.

\section{Australian Statistics}

ThE Official Year Book of the Commonwealth of Australia for 1934 (Commonwealth Bureau of Census and Statistics. 5s.) gives as usual an exhaustive summary of all aspects of Australian life and activity. The call of economy still hampers the editor in carrying out all his projects, but he has achieved great success in presenting information in forms that are useful to economists and others. Many details of the census of 1933 are incorporated. An appendix gives a summary of the chief events in connexion with the financial erisis that began in Australia in 1929 .

\section{Craftsmanship in Scientific Instruments}

The Physical Society announces that the seventh annual craftsmanship and draughtsmanship competition will be held as usual in conjunetion with its annual exhibition of scientific instruments and apparatus in January next. Competitors must be in the regular employ of a firm or institution which will be exhibiting or has exhibited at least once during the previous three years, and has been invited by the organising committee to enter its employees for the competition.

\section{Chinese Medical Association}

THE third general meeting of the Chinese Medical Association, the official medical association of China, will be held on November 1-8. This association is the successor to the China Medical Missionary Association organised in 1886. The 1935 meeting will be held at the Canton Hospital, Canton, China, because it was here that Dr. Peter Parker introduced Western medicine into China one hundred years ago. $\mathrm{He}$ was also the world's first regularly appointed medical missionary. A centennial "History of the Hospital" is now in the press (Kelly and Walsh, Shanghai). Besides the regular scientific sessions of the conference, November 2 will be devoted to the centenary celebrations. The new Canton Hospital will be formally opened, and the foundation stone will be laid for the new medical school building. The money for the latter has been obtained by a special grant from the Central Executive of the National Government of China.

\section{New Secretary of the Institution of Naval Architects}

MR. G. V. Boys has been appointed secretary of the Institution of Naval Architects, in succession to $\mathrm{Mr}$. R. W. Dana, who will retire at the close of this year, after thirty-four years of service as secretary. Mr. Boys, who is a son of Sir Charles Vernon Boys, is a graduate of Trinity College, Cambridge (Mathematical Tripos, Pt. 1, and Mechanical Science Tripos). $\mathrm{He}$ is an associate-member of the Institutions of Mechanical and Electrical Engineers, and was for some years a demonstrator in mathematics and mechanics at the Imperial College of Science and Technology; previous to this he was one of the founders of the University of Cambridge Engineering Society. For the past fourteen years he has been on the staff of Messrs. Kennedy and Donkin (consulting engineers).

\section{Royal College of Physicians}

The annual Harveian Oration was delivered on October 18 at the Royal College of Physicians by Sir Henry Dale, director of the National Institute for Medical Research, whose subject was "Some Epochs in Medical Research". The substance of the lecture is printed on p. 690 of this issue. The president of the Royal College of Physicians, Lord 